\title{
Intracranial mass of multiple myeloma with good response to chemotherapy
}

\author{
Nathalie E Synhaeve, ${ }^{1}$ Cees van der Heul, ${ }^{2}$ Cees C Tijssen ${ }^{1}$ \\ ${ }^{1}$ Department of Neurology, St Elisabeth Hospital, Tilburg, Netherlands; \\ ${ }^{2}$ Department of Internal Medicine, St Elisabeth Hospital, Tilburg, Netherlands \\ Correspondence to Nathalie E Synhaeve, n.synhaeve@elisabeth.nl
}

\section{DESCRIPTION}

A patient was admitted to the internal medicine ward because of hypercalcaemia. Additional diagnostic testing led to the diagnosis multiple myeloma. During admission, she gradually developed confusion and a left hemiparesis. Brain imaging revealed a large tumour mass extending into the brain (figure 1). The patient was treated with chemotherapy consisting of melphalan and bortezomib in combination with dexamethason, because the cognitive condition was too bad to treat the patient with high dose chemotherapy and autologous stem cell reinfusion. Neither could the patient be treated with radiotherapy because of the restlessness. Follow-up imaging 2 months later revealed almost complete disappearance of the intracranial tumour mass (figure 2). The clinical condition also completely recovered. Intracranial

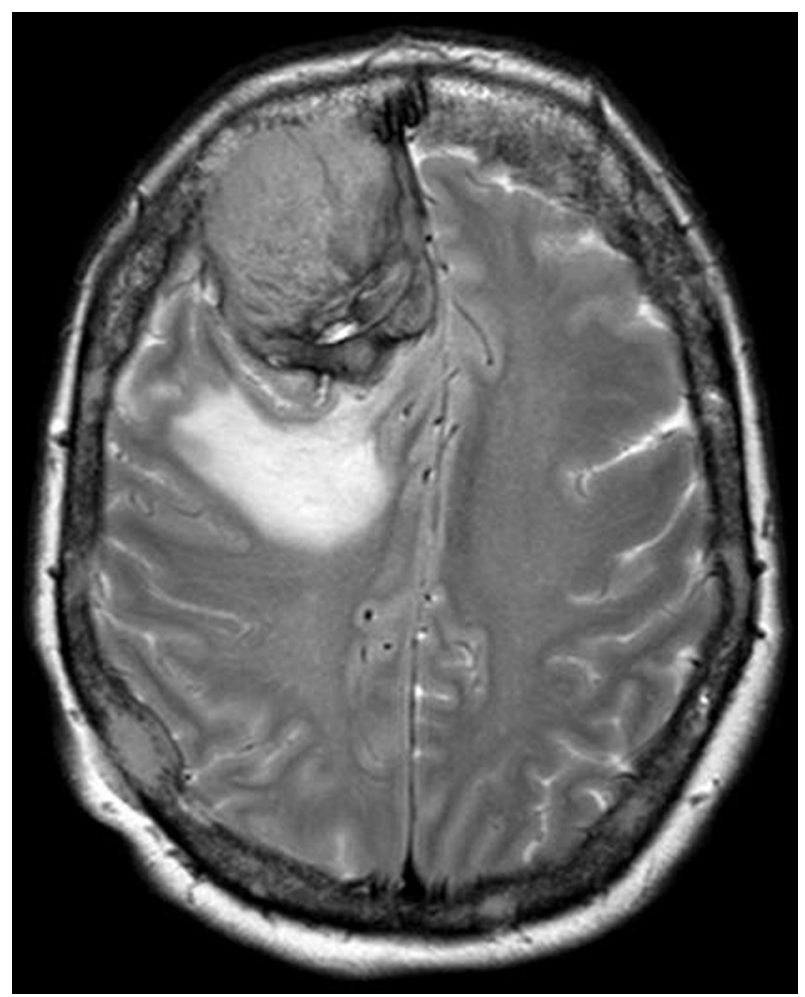

Figure 1 On MRI-scan a tumour in the right frontal part of the skull is seen, with intracranial expansion. tumours in patients with multiple myeloma are rare, especially as the first presentation. An important risk factor for the development of intracranial growth seems to be a p53-deletion in clonal plasma cells. ${ }^{1}$ The best way of treatment in case of intracranial tumour mass is not quite known. Few case reports promote systemic chemotherapy as the most important part of treatment. This is supported by our experience in the case presented which showed a complete response. This has not been documented earlier in such a way. Resection or radiation therapy may be possible alternative strategies, but no evidence-based treatment can be advised. Time of survival is comparable to the prognosis of multiple myeloma without intracranial progression. ${ }^{2-4}$ Treatment is not so much aimed at increasing survival, but aimed

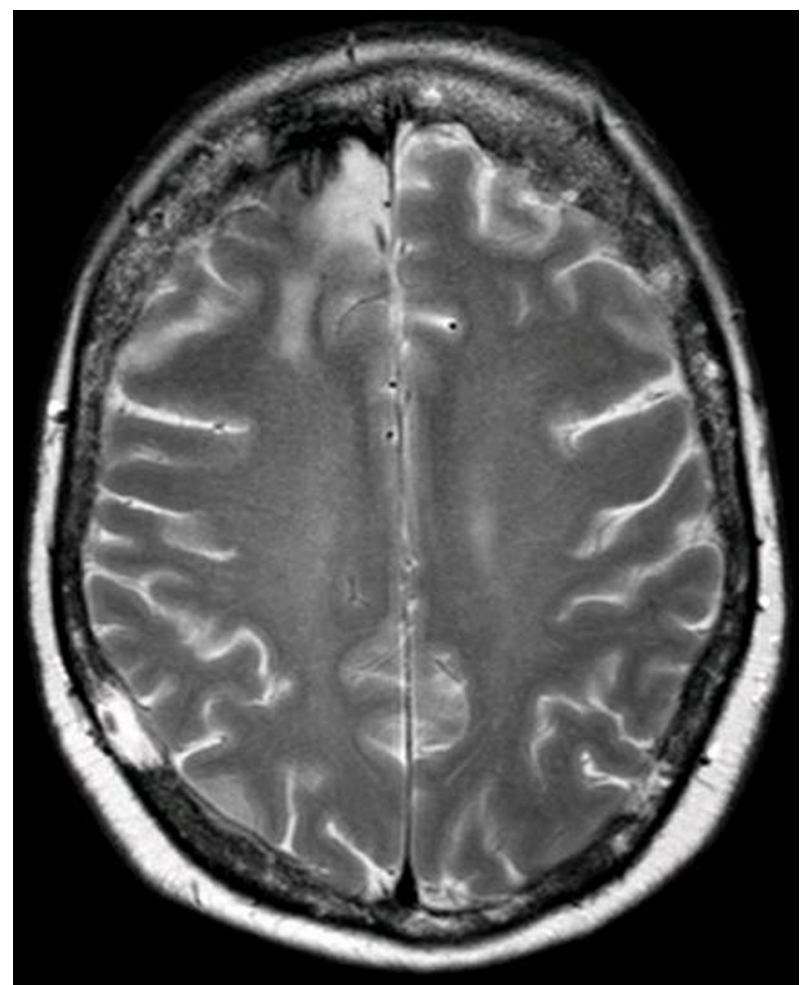

Figure $2 \mathrm{MRI}$-scan after treatment with chemotherapy. Apart from some minor residual abnormalities the tumour mass has completely disappeared. 


\section{BMJ Case Reports}

at improvement of quality of life. In this respect chemotherapy can be an attractive option as is demonstrated by our patient. The patient is deceased and there are no close relatives, therefore no written consent for the paper could be obtained. For this reason the case is anonymised (no gender, no age).

\section{Competing interests None.}

Patient consent Not obtained.

\section{REFERENCES}

1. Chang H, Sloan S, Li D, et al. Multiple myeloma involving central nervous system: high frequency of chromosome 17p13.1 (p53) deletions. Br J Haematol 2004;127:280-4.

2. Eum JH, Jeibmann $A$, Wiesmann W, et al. Multiple myeloma manifesting as an intraventricular brain tumor. J Neurosurg 2009;110:737-9.

3. Wavre A, Baur AS, Betz M, et al. Case study of intracerebral plasmacytoma as an initial presentation of multiple myeloma. Neuro-oncology 2007;9:370-2.

4. Cerase A, Tarantino A, Gozzetti A, et al. Intracranial involvement in plasmacytomas and multiple myeloma: a pictorial essay. Neuroradiology 2008;50:665-74.Queries for Author

This pdf has been created automatically from the final edited text and images.

Copyright 2012 BMJ Publishing Group. All rights reserved. For permission to reuse any of this content visit http://group.bmj.com/group/rights-licensing/permissions.

BMJ Case Report Fellows may re-use this article for personal use and teaching without any further permission.

Please cite this article as follows (you will need to access the article online to obtain the date of publication).

Synhaeve NE, van der Heul C, Tijssen CC. Intracranial mass of multiple myeloma with good response to chemotherapy. BMJ Case Reports 2012;10.1136/bcr.03.2012.5964, Published XXX

Become a Fellow of BMJ Case Reports today and you can:

- Submit as many cases as you like

- Enjoy fast sympathetic peer review and rapid publication of accepted articles

- Access all the published articles

Re-use any of the published material for personal use and teaching without further permission

For information on Institutional Fellowships contact consortiasales@bmjgroup.com

Visit casereports.bmj.com for more articles like this and to become a Fellow

Keep up to date with all published cases by signing up for an alert (all we need is your email address) http://casereports.bmj.com/cgi/alerts/etoc 